\title{
The Menace of Open Defecation in Ghanaian Communities: The Case of Gambaga and Nalerigu Communities in North East Region
}

\author{
Ibrahim Abudulai ${ }^{1}$, Tia Abdulai Robert Aziz ${ }^{2}$, Benjamin Ofori ${ }^{1}$, Godfred Atta Adjei ${ }^{3}$ \\ ${ }^{1}$ Department of Social Sciences, Gambaga College of Education, Gambaga, Ghana \\ ${ }^{2}$ Public Utilities Regulatory Commission, Accra, Ghana \\ ${ }^{3}$ Department of Social Sciences, Barekese Senior High School, Barekese, Ghana
}

Email address:

iabudulai76@yahoo.com (I. Abudulai)

\section{To cite this article:}

Ibrahim Abudulai, Tia Abdulai Robert Aziz, Benjamin Ofori, Godfred Atta Adjei. The Menace of Open Defecation in Ghanaian Communities: The Case of Gambaga and Nalerigu Communities in North East Region. International Journal of Environmental Protection and Policy. Vol. 9, No. 2, 2021, pp. 16-26. doi: 10.11648/j.ijepp.20210902.11

Received: February 19, 2021; Accepted: March 9, 2021; Published: March 30, 2021

\begin{abstract}
The study sought to investigate the open defecation menace in Ghanaian communities with emphasis on Gambaga and Nalerigu Townships in the North East Region of Ghana. A sample of 70 respondents comprising household heads and Environmental and Sanitation Officers was considered for the study. Purposive and non-probability sampling techniques were used to select the respondents for the study. As a qualitative study, questionnaire, structured interview guide, and personal observation were instruments for data collection. The study revealed among others that the inability of some households to provide toilets in their homes accounted for the state of open defecation in the two townships. Again, some residents in Gambaga and Nalerigu Townships practice open defecation because of the bad odour that emanates from the public toilets leaving bad smell on their entire bodies once they visit the toilets. It was recommended that government, Non-Governmental Organizations, and other philanthropists should assist residents of Gambaga and Nalerigu by assisting them with some credit facilities to empower them to improve on their economic activities especially agriculture to earn enough income for the construction of their household latrines. It is also, recommended that the Municipal Assembly should replace the old public toilets with WC toilets to reduce the amount of odour that emanates from such old pit latrines.
\end{abstract}

Keywords: Communitiess, Township, Defecation, Sanitation

\section{Introduction}

Environmental sanitation tries to develop and maintain a clean, safe and good physical and natural environment in all human settlement, to enhance the socio-cultural, economic, and physical well-being of all aspects of the population [1]. This involves other activities, including the provision and maintenance of sanitary facilities, the provision of services, public education, community and individual action, regulation and legislation supported by clearly mandated institutions, adequate funding and research and development. Sanitation is one of the most important determinants of the quality of life but it is often times neglected. Human existence on this earth depends on the quality of the environment. The term environment refers to the air, water, and the land around us. These elements provide significant relevant services such as habitat in which to live and resources to produce goods and services [2]. This indicates that one cannot do away with the environment; hence, the need to protect the environment. The environment is gradually deteriorating and this is as a result of negative human activities such as open defecation leading to poor sanitation and other environmental issues. This resulted in the United Nations call for sanitation facilities accessibility to 1.8 billion people between 1990 and 2010 [3]. This period has elapsed yet, the issue persists. In Ghana, for instance, the country is only able to improve its sanitation by $1 \%$ every year [4].

Open defecation as a link of sanitation is the practice where individuals or households dispose of faeces in fields, 
forests, bushes, open bodies of water, beaches or other open spaces, or with solid waste [5]. People practice open defecation as a result of inadequate/lack of toilets, latrines, or any kind of improved sanitation in their environment. Unsafe management of human excreta and poor personal hygiene are closely linked with diarrhoea as well as parasitic infections, for instance, soil-transmitted helminths (worms) (p. 18) [5]. They also maintain that improved sanitation and hygiene can bring down diarrhea disease by more than a third and significantly lessen the health impacts of soil-transmitted helminth infections and all kinds of neglected tropical diseases which affect people. Open defecation threatens people's lives with cholera, hepatitis A, diarrhoea, dysentery, and other sanitation-related diseases, increasing the mortality rate of people particularly children [6]. In 2015, it was estimated that 892 million people were still practicing open defecation and at least 60 million people need to stop the practice each year between 2015 and 2030 [7]. The SDG 6 which Ghana is a signatory calls for access to adequate and equitable sanitation and hygiene for all and to end open defecation, paying special attention to the needs of women and girls and those in vulnerable situations [7]. But, UNICEF's vision is far from been achieved; because it is estimated that only 18 countries are on track to eliminate open defecation by 2030; globally, three times the current progress is needed to end open defecation by 2030 [7]. There is, therefore, no doubt that the open defecation situation in the Gambaga and Nalerigu Townships is in one way or the other negatively affecting Ghana's quest to meet the SDGs 6 in 2030. The basis for this assertion is that unlike rural communities such as Guabulga, Nayoku, Sagadugu, and Wulugu all in the West Mamprusi Municipality where conscious efforts are being made to end open defecation by way of social mobilization for sanitation and hygiene promotion, the case of Gambaga and Nalerigu Townships is quite complicated. These two townships are cosmopolitan and multi-cultural.

Reduction in open defecation is recognized as a top priority for improving health, nutrition, and productivity of developing countries as it is explicitly mentioned in SDG target 6. As of the year, 2020, Gambaga and Nalerigu Townships were contributing to Ghana's off-track to eliminating open defecation by 2030. There are a high prevalence of open defecation in all the sixteen (16) regions of Ghana as a result of lack of access to toilet facilities [8]. Can same be said of Gambaga and Nalerigu Townships; the gap this study seeks to investigate. The researcher's prime objective, therefore, is to assist East Mamprusi Municipal Assembly in the North East region of Ghana to eliminate open defecation in Gambaga and Nalerigu Townships. This will result in assisting Ghana to achieve the SDG target 6 by the year 2030 .

\section{Study Area}

Gambaga and Nalerigu are the largest towns in the East Mamprusi Municipality in the North East Region of Ghana.
East Mamprusi Municipal is one of the 260 Metropolitan, Municipal and District Assemblies (MMDAs) in Ghana, and forms part of the 6 MMDAs in the North East Region. The Municipality was established by Legislative Instrument (LI) 1776 (2004) with the capital located at Gambaga and it covers a landmass of 1,706.8 square kilometers [9]. It is one of the oldest Municipalities in the North East Region; out of it, the West Mamprusi Municipal was carved in 1988. In 2004, the Bunkpurugu Nankpanduri District was also created to promote development. It, therefore, serves as the parent District for West Mamprusi Municipal and Bunkpurugu Nyankpanduri Districts. The East Mamprusi Municipality shares boundaries with Talensi and Nabdam Districts, Bawku West and Garu Districts, all in the Upper East Region, and to the east are the Bunkpurugu Nankpanduri District. It is bordered in the west by the West Mamprusi Municipal and to the south by the Gushegu Municipal and Karaga District. The population of the Municipality according to the 2010 Population and Housing Census stands at 121,009 with 59,453 males and 61,556 females [8].

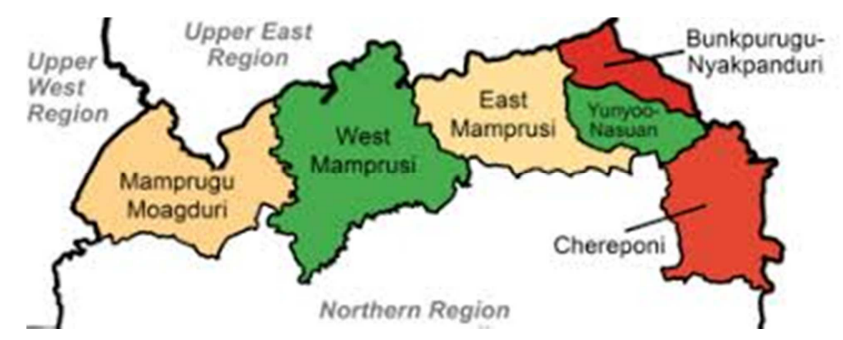

Source: https://en.wikipedia.org/wiki/East_Mamprusi_Municipal_Assembly

Figure 1. Map of Northern Region showing East Mamprusi Municipality.

As major towns in the East Mamprusi Municipality, Gambaga and Nalerigu are well known for their stable, peaceful communities and population that is largely friendly. Gambaga and Nalerigu are the traditional homes of the Mamprusi people. Nalerigu is the seat of the Paramount Chief; thus, the "Nayiri." Nalerigu is also the capital of the North East Region of Ghana. Both Gambaga and Nalerigu Townships are divided into areas. For instance, Nalerigu Township is divided into eight areas/sections comprising "Nayiri fong", "Abaabu, Kpariboa fong", "Bimonaa fong", "Dundan fong", "Atabiya fong", "Mba Asuma fong", "Busaansi fong", "Asibiti fong", Kulugu Duuri", and "Fafra fong." But, originally, the Township was divided into three major sections such as "Nayiri fong", "Abaabu", "Kpariboa fong." Gambaga, on the other hand, has four areas/sections comprising "Nakosigu fong", "Gambarana fong", "Luman fong" and "Sibiya fong." These areas/sections of household heads will be purposively and conveniently selected for the interview.

\section{Statement of the Problem}

Currently, Ghana is implementing the Rural Sanitation Model and Strategy (2010) to improve sanitation including open defecation in rural areas and future urban areas 
(UNICEF/CDD, 2019). The number of people practicing open defecation in Ghana was reported at $18.75 \%$ in 2015 [9]. Households that have no toilet facilities of any kind available for use at home in the Gambaga and Nalerigu Townships mostly resort to the use of the bush or the field. The seriousness of the situation is that children are the leading culprits, particularly because toilet facilities are usually not designed to meet their needs [10]. They maintained that though open defecation is predominantly a rural phenomenon, it is estimated that $8.22 \%$ of the urban population in subSaharan Africa practice open defecation. Open defecation is increasingly becoming alarming in the Gambaga and Nalerigu Townsips, putting residents at the risk of sanitationrelated diseases such as cholera, diarrhoea, and typhoid. In Gambaga and Nalerigu Townships human faeces are commonly found in open spaces and in-between houses, some rapped in black polythene bags, with the resultant stench and flies nuisance. The sight and smell of faeces within residential areas especially the core of the two townships, reduce the aesthetic quality of the environments and causes embarrassment to residents and visitors to the municipality. But, it is worth mentioning that the importance of Gambaga and Nalerigu Townships to the development of the nation cannot be overemphasized because of their attractiveness as tourist destinations in the North East Region of Ghana. Nalerigu has these tourist sites; Doves Caves, Nayiri Palace, and Naajeringa Wall. Gambaga also has Mossi chiefs' ancestral gravesites, the pre-historic Gingana rock paintings, and Gambaga Escarpment. Important tourist destinations such as these need clean and sanitized environs. Uninterestingly, these beautiful environments are marred by the practice of open defecation leading to poor sanitation in the two Townships. For instance, $86.0 \%$ of households in East Mamprusi Municipality of which Gambaga and Nalerigu are major towns use the bush/field while 5.8 percent use public toilets and only 4.3 percent use KVIP [8]. The proportion of households in Gambaga and Nalerigu Townships that have no toilet facilities is 70.5 percent, those using a public toilet is 14.2 percent and 8.9 percent relies on KVIP [8]. As of the year 2020, the open defecation situation has not changed. An observational tour of areas within Gambaga and Nalerigu Townships saw people especially children and women squatting around the premises of public toilets, backyards, as well as bushes attending to nature's call openly. Some people defecate in polythene bags and they throw it where ever they like. This at times breeds and attracts flies leading to diseases like cholera, typhoid, and diarrhea, among others. It is so worrying that open defecation is not being practiced only in the night but in the full glare of everyone in the day time in bushes within both townships. The situation is compounded during the rainy season. There is no sign that the advocacy campaigns to stop open defecation in Ghanaian communities by the government, WHO and UNICEF is being heeded to by the people of Gambaga and Nalerigu Townships. It is against this drawback that the study sought to investigate factors influencing open defecation practices, challenges involved in curbing open defecation, and suggestions for the way forward in curbing the menace in these two major communities.

\section{Research Questions}

What are the factors influencing the practice of open defecation in Gambaga and Nalerigu Townships in the North East Region of Ghana?

What are the challenges in curbing the menace of open defecation in the Gambaga and Nalerigu Townships in the North East Region of Ghana?

What is the way forward for curbing the practice of open defecation in the Gambaga and Nalerigu Townships in the North East Region of Ghana?

\section{Review of Literature}

\subsection{Meaning of Open Defecation}

Open defecation can be explained as the practice of defecating in the open spaces, waterways without any proper disposal of human excreta $[11,12]$. Open defecation can also be seen as human practice of defecating in the open rather than into the toilet. This is where human faeces are disposed of in the fields, forests, bushes, and open bodies of water, beaches, and other open spaces [13]. Defecating in the open is an old practice. In ancient times, there were availability of spaces and limited population pressure on the use of land. It was perceived that defecating in the open spaces causes little harm on people. But, with development and urbanization, open defecating started becoming an issue of public health and human dignity [14]. More attention was given to hygiene and health; hence, increased in global attention towards reducing the practice of open defecation.

\subsection{Implications of Open Defecation on the People in the Community}

Diarrhoea is the third most common disease in the communities due to the continuous practice of open defecation; Cholera, diarrhoea, typhoid, and dysentery are among the diseases troubling people in the communities which affect the health and wellbeing of the people [15]. Infected human excreta contain several harmful organisms that are associated with several health problems. Inappropriate human waste disposal also increases the risk of exposure to these pathogens which can pose significant health risks such as transferable infectious diseases, diarrhoea, typhoid and cholera and viral infections [16]. WHO reports that 1.8 million people in low and middle-income countries suffer from severe trachoma [17]; a root cause of visual impairment which is transmitted via flies that breed on human excreta with a tendency to spread through eye discharge of infected persons [18]. Likewise, more than 200 million people are infected with schistosomiasis (snail fever) worldwide [17]; a chronic parasitic disease transmitted through human faeces to freshwater snails and the infection 
spread in humans when the skin comes in contact with infection carrying snails or consumption of contaminated water and modulate their immune systems [19]. Improved sanitation interventions can play a constructive role in disease prevention, including diarrhea and soil-transmitted infections [20].

Sanitation has a major impact on individual human rights, explaining that health implications linked to access to clean water, poor sanitation, and open defecation are clear breaches of human rights [21]. UN asserts that sanitation has to be considered beyond the scope of just considering health, housing, education, work, and gender equality but instead should be considered in terms of human dignity in that open defecation evokes feelings of vulnerability and shame and this infringement to human dignity should be considered a human rights issue.

\section{Methodology}

Table 1. Summary of Respondents.

\begin{tabular}{ll}
\hline Number of Household Respondents & 60 \\
Number of Environmental and Sanitation Officers & 10 \\
Total & 70 \\
\hline
\end{tabular}

Source: Field data (2020)

\subsection{Research Design}

Social survey was used with a descriptive design aimed at determining the influences of open defecation, challenges in curbing open defecation, and suggestions for the way forward for the elimination of the practice of open defecation in the Gambaga and Nalerigu Townships in the North East Region of Ghana.

\subsection{The Population of the Study}

The population for the study was all residents of Gambaga and Nalerigu Townships. The target population was 60 household heads and 10 Environmental and Sanitation workers in Gambaga-Nalerigu Municipality. This was adequate to attain the standards of thematic saturation in qualitative research [22]. The sanitation workers were considered because they have been given the responsibility of educating people on the negative effects of the practice of open defecation and taking care of sanitation issues in the community in general. They are therefore in a position to tell the challenges they encounter and suggestions for the way forward in trying to stop the practice of open defecation. Household heads or residents within the townships were part of the target population because they practice open defecation.

\subsection{Sample and Sampling Technique}

Two major towns were considered for the study. This is because they are at the heart of the North East Region of Ghana, more populated and a bit closer to each other as compared to other towns in the Region. This was to make the researcher's study relatively convenient and faster. The researcher considered all the fifteen (15) areas in Gambaga and Nalerigu Townships. Four (4) household heads were purposively selected and interviewed; thus, 44 household heads in Nalerigu and 16 household heads in Gambaga totaling sixty (60) household heads. A self-designed questionnaire was also given to ten (10) Municipal Environmental and Sanitation Officers to respond to. The sample size for this study was, therefore, seventy (70) respondents. A detail of the areas and the number of respondents interviewed are shown in Table 1. Purposive sampling was used to select the Environmental and Sanitation Officers.

\subsection{The Instrument for Data Collection}

To gather the most accurate and dependable data concerning the research questions, three data collection instruments were employed. These were the interview guide, questionnaire, and self-observation as instruments for gathering data. The questionnaire was given to only Gambaga-Nalerigu Municipal Environmental and Sanitation workers to respond to. The self-designed questionnaire had close-ended and open-ended items. The closed-ended items have statements of which the respondents were asked to tick the most appropriate answers to the statements. The openended items were to seek the views of the Environmental and Sanitation workers on the challenges they face in fighting the open defecation menace and the way forward in eliminating the canker in the two major towns.

\subsection{Data Analysis}

The researcher used both descriptive and interpretive techniques to analyze the data based on research questions for the study and the number of issues raised by respondents. Responses from the interviews were transcribed and responses were used in the analysis of the study. Again, direct quotations of respondents were used where applicable. Simple percentages, tables, and words were also used to analyze the quantitative data.

\section{Findings and Discussions}

\subsection{General Findings}

The study revealed that $70(100 \%)$ comprising sixty (60) household respondents and ten (10) Environmental and Sanitation workers agreed that open defecation is a common practice in the Gambaga and Nalerigu Townships which to them is not a good practice. For instance, one of "trq?these respondents said: "Looking at open defecation, to me is not good practice because of bad odor that comes from the surroundings especially when it rains is unbearable and not healthy; even houseflies can sit on the faeses and bring sickness into our homes" (Field interview, 2020).

The study also revealed that $60(100 \%)$ of the household respondents interviewed, all agreed, when a question was asked: Is it safe for women and children to openly defecate in 
our areas? All respondents agreed that defecation openly, in general, is not good for a human being not to talk of women who are vulnerable to diseases, rapists, among others. Religious, traditions, hygiene, and criminal attacks were also reasons assigned to their stand on women being vulnerable in the activity of open defecation. One of these respondents who was a female said this on women and open defecation:

"We women have a lot of secretes which need not be exposed to the public. For example, as a woman, I can go out to the bushes around to defecate and my menses start; at that particular place I cannot call for assistance and messing the place with blood too in public view is not hygienic. The only option left for me do is to mess myself up back home which can be disgraceful." (Field interview, 2020)

Another household respondent who is a male also stated the reasons why women should not openly defecate on religious grounds. He said:

"Religiously it is a sin for a woman to expose certain parts of her body to a man who is not her husband, and also it is sin for a man to also look at the naked body of a woman who is not his wife. So, a situation where both men and women freely defecate openly exposes the women vital parts of her body to the religiously unacceptable public." (Field interview, 2020)

One of these respondents also argued on women vulnerability to nefarious activities of rapists and put it in this way: "You know a man body is not attractive like a woman; so, when women openly expose their bodies as a result of defecation, men who are not morally upright can decide to rape them."(Field interview, 2020). For children, all respondents said they are prone to bites of reptiles such as snakes and infections such as cholera, typhoid, among others.

Results of the study also indicated that out of the 60 household respondents selected for the interview, only $3(2 \%)$ of them mentioned that they have the household latrine in their houses. The remaining 57 (34\%) respondents do not have household latrines in their homes and attributing that to the cost of construction one; is the basis for which they resort to defecating openly.

Figures showing the state of public toilet and open defecation site in Gambaga and Nalerigu Townships

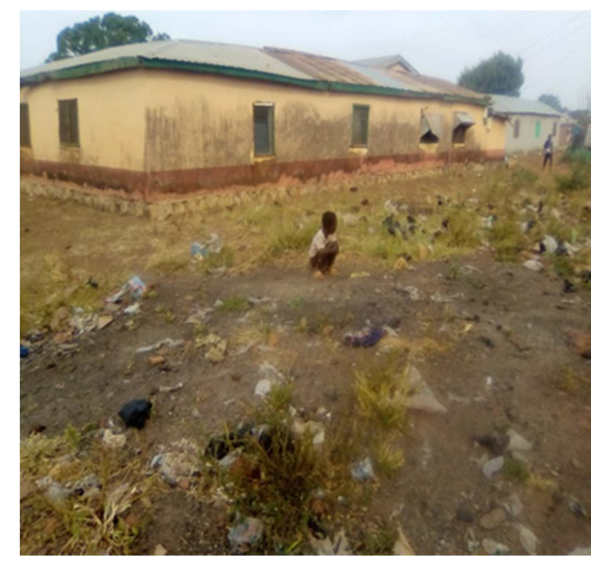

Figure 2. Open defecation site within houses.

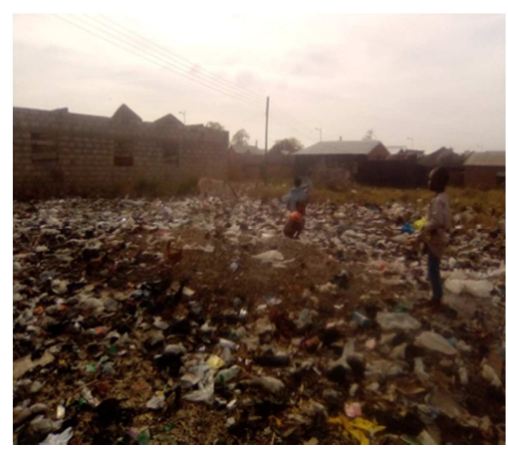

Figure 3. Open defecation outside a public toilet

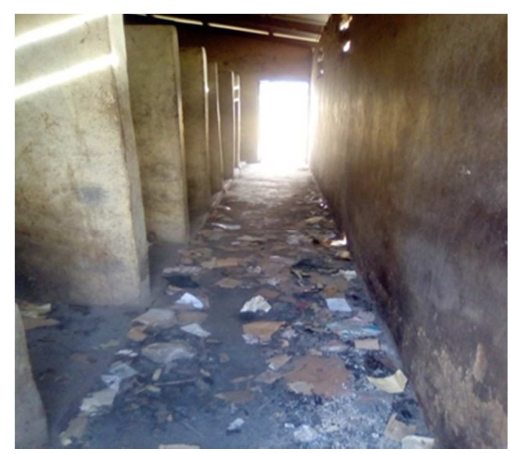

Figure 4. Entrance of a public toilet with faecal.

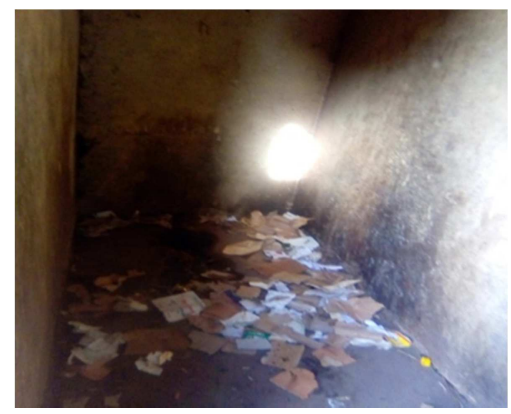

Figure 5. Messes inside of a public toilet.

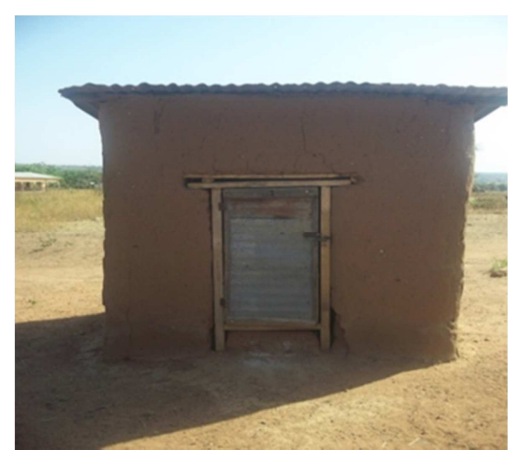

Figure 6. Full up household latrine.

Figure 1 shows a child openly defecating within available space in houses. Figure 2 indicates children openly defecating outside the premises of a public toilet. Figure 3 is a current state of an entrance of a functioning public toilet. Figure 4 indicates the mess inside a functioning public toilet. Figure 5 is a household latrine that is full waiting dislodging while Figure 6 is the backside of a functioning public toilet. This indicates that the nature of the toilets precludes people 
from using public toilets.

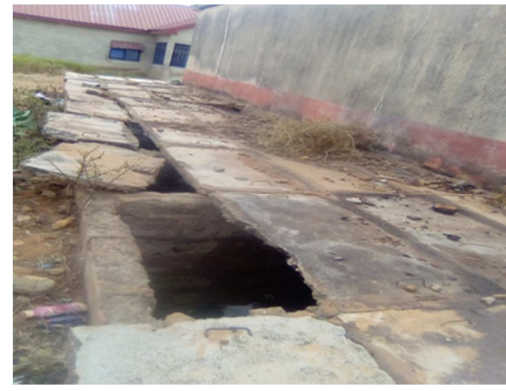

Source: field observation, 2020

Figure 7. Back of deplorable public toilet.

\subsection{Factors Influencing the Practice of Open Defecation in Gambaga and Nalerigu Townships}

In the researcher's quest to answer this research question, household respondents were asked to mention the main reasons why residents in their areas engage in open defecation. The following responses came up from respondents as the factors that influence open defecation in their areas:

\subsection{Inadequate Public Toilets}

According to the household respondents interviewed public toilets both in Gambaga and Nalerigu Townships are woefully inadequate for them due to the teeming population of the towns. The study revealed that $60(100 \%)$ of the household respondents interviewed attributed the widespread open defecation to inadequate public toilets and household latrines. Most of these respondents complained of one public toilet serving two large areas/sections. For instance, in Nalerigu Township the areas called "Abaabu" and "Bimoba fong" have one public toilet sited in "Abaabu" So, residents in "Bimoba fong" find it convenient engaging in open defecation than walking far distance to do same. Some of these respondents added that their situation becomes pathetic if one is having diarrhoea. In Gambaga too, one public toilet is serving both "Nakosigu fong" and "Assemble area" These are large areas that need more than just one public toilet. The researcher's personal observation also revealed that there are only thirteen (13) public toilets both in Gambaga and Nalerigu Townships with their huge population density; thus, nine (9) public toilets in Nalerigu and four (4) in Gambaga. There are still about 1.1 billion people who have no access to any form of toilet facility which compels them to defecate openly; thereby causing serious sanitation challenges to human lives [23]. Few public toilets are over-utilized and poorly managed [24]. This challenge was also noted by the United Nations for which they have endeavoured to make sanitation facilities accessible to 1.8 billion people between 1990 and 2010 [3]. But, the issue of open defecation persists. The researcher's observation revealed that this is a prevailing situation in all areas of Gambaga and Nalerigu Townships.

\subsection{The Poor State of Public Toilets and Latrines}

The inadequate public toilets situation in Gambaga and Nalerigu Townships has put pressure on the usage of the existing public toilet facilities; thereby leading to their deplorable and poor state making them not conducive now for use; hence compelling residents to resort to defecating openly. The respondents expressed their feelings that using the filthy, hot, and smelly toilet facility waste their time bathing all the time. Also, the bad odour emanating from the toilets leaves a bad smell on their entire body which makes it difficult to mingle with other individuals once they visit the toilets. One of these respondents stated this: "For me, I only use the public toilet when am ready to bath; because after using the public toilet I smell, preventing me from going to gatherings." (Field interview, 2020). The expressions of these respondents indicate that the toilet facilities in both Gambaga and Nalerigu Townships especially the public toilets are very smelly and filthy which waste some of them their time bathing frequently especially if one is running diarrhoea and this prevents them from using the toilets thereby resorting to open defecation.

\subsection{The Economic Influence of Open Defecation}

The findings of this study also revealed that money has a big role in influencing open defecation in Nalerigu and Gambaga Townships. One of the 3 respondents who mentioned that they have latrines in their homes raised an issue which might be the plight of the silent majority which to the researcher needs to be tackled. She said:

"This house we have our latrine, but our bigger challenge is, it is full up. It cannot be used again, we can go out and you see it for yourself. We heard there is a cost involved when an Assembly vehicle comes to remove the waste. Sometimes we are compelled to go out openly to defecate." (Field interview, 2020)

This indicates that this respondent finds it difficult in getting the cesspit emptier a truck to empty their toilets due to financial constraints and this compels household members to abandon the toilet facility and resort to the forest and refuse dumps.

The study also disclosed that 57 (39.9\%) of the household respondents interviewed in Gambaga and Nalerigu Townships are not using household toilets. These respondents wished they could construct their latrines but they are financially handicapped compounded by the rocky nature of the land especially parts of Nalerigu Township. These compel residents to resort to open defecation in the bushes and into polythene bags for which they later throw into the bushes or the fields. One of these respondents in Nalerigu said:

"We want to construct our latrines but there is no money to get a machine to dig the pits for us. Look the whole of Nalerigu Township is full of rocks. Take from this area (Dundan) through "Abaabu" to "Bimoba fong" are all rocky. I dug one for myself up to my waist level but got to rocks and abandoned it because no money to rent a machine to 
complete it for me. If the government could support us with the machines, we will all have latrines in our houses." (Field interview, 2020)

\subsection{Health Factor Influencing the Open Defecation}

On the issue of health as a factor influencing open defecation, the study revealed that most residents do not know how to use the available public toilets hygienically. For example, $57(34 \%)$ of the household respondents indicated that the maggots at the public toilet facilities, the bad odour, and the heaped faeces cause them to feel nauseous upon seeing things of such nature. They emphasized that the filthy toilets cause them body itching. But, defecating openly in the bushes and fields, they do not experience these scenes. Some of these respondents also expressed their views that the bad odour and the heat that emanate from the toilet holes are unhealthy especially for women who can be infected with candidiasis (whites). For some of these respondents too, inhaling the unpleasant air causes people especially asthmatic persons to suffer inside the toilet facilities. For these respondents, it is better and safe to openly defecate to avoid these unacceptable scenes. One female respondent in Gambaga expressed this view:

'I don't use the public toilet, because some people do not know how to use them. Also, as a woman, the heat emanating from beneath the toilet makes me contract candidiasis. So I prefer open defecation to the use of a public toilet facility for which I have to seek treatment after visiting it (Field interview, 2020)

The narration above indicates that the female respondent resorted to defecating in the open for the fear of contracting candidiasis and other infectious diseases.

\subsection{Responsibility Shift of Environmental and Sanitation Officers}

The Environmental and Sanitation Officers are mandated to sensitize the general public on the need to keep a safe and clean environment for better healthy living of the people. Sanitation workers under the Sub-Metro/Zonal Urban Councils are assigned the responsibility for selected common services best rendered from the sub-district office, such as i) Food hygiene and other inspection work ii) Environmental sanitation education iii) Cleansing, iv) Supervision of contractors, and v) Co-ordination, support and supervision of services within the sub-district [25]. This implies that Gambaga-Nalerigu has sanitation workers in charge with the responsibility of sensitizing the general public on the negative effects of open defecation and other best practices of sanitation through community engagement in radio programmes, among others. This study revealed that $59(35 \%)$ of the household respondents interviewed believed that Municipal Sanitation Officers are not seen performing the above responsibilities effectively. They are rather seen effectively performing the roles of the Town and Country Planning department; thus, demarcation of lands into plots for people. For these respondents their new role is lucrative; hence, the cause for the shift. When the researcher asked the respondents whether they know the people to contact on sanitation issues, $59(35 \%)$ of the household respondents mentioned the Assemblyman as the one they know can assist them. One of these respondents said: "We have been complaining to our Assemblyman, but sometimes the Assemblyman has a lot of issues at hand to solve; but, they are also not been paid. So, we are just praying." (Field interview, 2020) Still, to buttress this view expressed by this respondent above, another male respondent said:

"I think open defecation is going on in the Municipality because the sanitation workers (samasama) are interested in the work that will give them big money rather than sensitizing the people on open sanitation issues. Most of our sanitation workers are engaged in demarcating plots for people. See, if the "samasama" go to the radio and announced that people should clean their houses and stop open defecation, it will be done fast; because if you refuse and they summoned you at the chief palace he will not hesitate to punish you." (Field interview, 2020)

\subsection{Poor Town Planning}

Though there is currently a shift from the construction of public toilets to the provision of household latrines, household heads respondents still felt that adequate planning was not made to leave enough demarcated land within these towns for future use by the Municipal Assembly for the provision of public toilet facilities. This view was expressed by $40(24 \%)$ of the household respondents who said they are willing to come together to contribute to constructing public toilets for themselves in their areas but the issue is whose land they will use for the construction of the facilities. One of these respondents from the "Assembly area" in Gambaga added that sometimes they even think of digging pits to defecate in and bury it; but, whose plot or land they are going to use for that purpose. These issues, coupled with the proximity of existing toilet facilities to residents' homes in the two major towns compel them to resort to open defecation.

\subsection{People Attitude}

The study revealed that open defecation is attitudinal. It was realized that there are people who resort to free-range because they want to hide and smoke so that they will not be noticed. For this respondent, such individuals will not succumb to any sensitization on the health implications of open defecation.

\section{Challenges in Curbing Open Defecation in the Gambaga and Nalerigu Townships}

To answer this question, ten (10) Environmental and Sanitation Officers were given a close-ended and open-ended questionnaire to respond to and these were their responses as 
shown in table 2 below:

Table 2. Challenges in curbing open defecation.

\begin{tabular}{|c|c|c|c|c|c|c|}
\hline No. & Challenges in Curbing Open Defecation in The Gambaga and Nalerigu Townships. & SD & $\mathbf{D}$ & $\mathbf{N}$ & $\mathbf{A}$ & SA \\
\hline 1 & Open defecation is a menace (challenge) in Gambaga and Nalerigu Townships. & --- & -- & -- & 6 & 3 \\
\hline 2 & $\begin{array}{l}\text { To the best of my knowledge, the people of Gambaga and Nalerigu Townships have been educated } \\
\text { about the negative effects of open defecation on human health and tourism. }\end{array}$ & -- & -- & -- & 4 & 5 \\
\hline 3 & $\begin{array}{l}\text { To the best of my knowledge, the people of Gambaga and Nalerigu Townships have not received } \\
\text { public education on open defecation to enable them to stop the practice. }\end{array}$ & 2 & 7 & -- & -- & -- \\
\hline 4 & There are adequate public toilets in Gambaga and Nalerigu Township for use by the people. & 2 & 7 & -- & -- & -- \\
\hline 5 & $\begin{array}{l}\text { There is too much interference from chiefs, leaders, and elders in Gambaga and Nalerigu Townships } \\
\text { when it comes to the prosecution of culprits/victims of open defecation. }\end{array}$ & -- & 2 & -- & 6 & 1 \\
\hline 6 & $\begin{array}{l}\text { The Gambaga and Nalerigu Municipal Environmental and Sanitation Units are understaffing to carry } \\
\text { out effective public education on open defecation. }\end{array}$ & 1 & 3 & -- & 3 & 2 \\
\hline 7 & $\begin{array}{l}\text { The cordial relationship between Environmental and Sanitation Officers affects the fight against open } \\
\text { defecation in Gambaga and Nalerigu Townships. }\end{array}$ & 2 & 5 & -- & 1 & 1 \\
\hline
\end{tabular}

Source: Field data (2020)

Where $\mathrm{SD}=$ Strongly Disagreed, $\mathrm{D}=$ Disagreed, $\mathrm{N}=$ Neutral, $\mathrm{A}=$ Agreed, and $\mathrm{SA}=$ Strongly Agreed

Data in Table 2 above show that $10(100 \%)$ of the Environmental and Sanitation Officers who responded to the close-ended questions agreed that open defecation is a menace (challenge) in Gambaga and Nalerigu Townships, no respondent disagree and no respondent was neutral; From table 2, $10(100 \%)$ of the respondents agreed that to the best of their knowledge the people of Gambaga and Nalerigu Townships have been educated about the negative effects of open defecation on human health and tourism, no respondent disagreed or took a neutral position; $10(100 \%)$ of the respondents disagreed that to the best of their knowledge the people of Gambaga and Nalerigu Townships have not received public education on open defecation to enable them to stop the practice, no respondent agreed with the statement and took a neutral position. Contrary, the responses from household heads indicate that they have not been receiving open defecation from the sanitation workers in the Municipality. From table 2 also, 10 (100\%) of the respondents agreed that there are adequate public toilets in Gambaga and Nalerigu Townships for use by residents, no respondent disagreed and took a neutral position on this statement. However, household heads have contrary views on this issue as $60(100 \%)$ of these respondents said they resort to open defecation as a result of inadequate public toilets. From table 2, $2(0.2 \%)$ of the Environmental Sanitation respondents disagreed with the statement that there is too much interference from chiefs, leaders, and elders in Gambaga and Nalerigu Townships when it comes to the prosecution of culprits/victims of open defecation; but, rather mentioned political leaders as those who normally interfere in the prosecution of culprits of open defecation in these two towns, $8(0.8 \%)$ of the respondents agreed to the statement, with no neutral stand or position. Also, $4(0.4 \%)$ of the sanitation officers disagreed with the statement that Gambaga and Nalerigu Municipal Environmental and Sanitation Department is understaffed to carry out effective public education on open defecation, no neutral stands on the statement, and $6(0.6 \%)$ of the respondents agreed with the statement; finally, $7(0.7 \%)$ of the sanitation officers disagreed with the statement that the cordial relationship between Environmental and Sanitation Officers affect the fight against open defecation in Gambaga and Nalerigu Townships, no neutral stands on this statement, and $3(0.3 \%)$ of the respondents agreed with the statement.

Equally, the Environmental and Sanitation Officers also gave these responses when an open-ended question demanding of them to state any other challenges they face in trying to curb the open defecation menace in Gambaga and Nalerigu Townships which are not stated in the close-ended statements. These challenges were mentioned by the Environmental and Sanitation officers:

Inadequate financial support from the Municipal Assembly to enable the Environmental and Sanitation officers to carry out their monitoring and supervision effectively.

Lack of enforcement of Municipal Assembly bye-laws. This makes it difficult for the Environmental and Sanitation Unit in the Municipality to function effectively.

Lack of effective monitoring of areas in towns to ensure compliance with Environmental and Sanitation best practices due to inadequate staff to be assigned to areas in the Municipality.

Lack of technical know-how among members of the two townships in assisting to construct their pit latrines.

Political and traditional leaders' interference in prosecuting offenders of open defecation in the Municipality.

The unwillingness of the people to change their attitudes towards open defecation is due to illiteracy and inadequate finance to construct their household latrine.

\section{The Ways Forward in Curbing Open Defecation in Gambaga and Nalerigu Townships}

To answer this research question and provide empirical suggestions for the elimination of open defecation by the rightful body mandated in the Gambaga-Nalerigu Municipality, household residents were selected and interviewed, and also Environmental and Sanitation Officers were given a questionnaire to respond to. From the study 
these responses were obtained:

\subsection{Suggestions of the Ways Forward from Household Heads}

Subsidizing the cost of construction of pit latrines

Respondents' views were sought on how open defecation could be stopped in Gambaga and Nalerigu Townships. 60 $(100 \%)$ of the respondents suggested that the provision of household latrines to every household is a major step for ending open defecation which will lead to total sanitation in the two major towns in the Municipality. These respondents also suggested that the implementation of laws and bye-laws by the Environmental and Sanitation Department in the Municipality will equally be important in eliminating open defecation in Gambaga and Nalerigu Townships.

Public education

It is only through education that the final solution can be found to any social challenge, especially when it comes to abolishing attitudinal prejudices. Education and sensitization must guide people to know the dangers of open defecation and how to avoid it. Minority ethnic groups should also be involved in the planning of education and sensitization activities through implementation and evaluation. It is on these bases that household heads in Gambaga and Nalerigu are of the view that open defecation can be eliminated in the two major towns if public education on the negative effects of open defecation is intensified. These respondents believed that many residents who engage in open defecation are not aware of the consequences of their acts, hence, their difficulty in changing their attitude towards open defecation. But, it is important to note that behaviour change is necessary because man can never benefit by acting against nature but he can benefit only by co-operating with nature [25]. The residents expect the Environmental and Sanitation Department in the Municipality to carry out their public education and advocacy in ending open defecation through local radios, religious bodies, and unit committee members. In these respondents' view, radio broadcasts and announcements are termed as effective in information dissemination on health issues. Public education not adequately and effectively carried out by the Sanitation Department in the Gambaga and Nalerigu Municipality, hence, the high prevalence rate of open defecation in these two townships.

Incentives to household heads

The household heads who were interviewed all stated that the fight against open defecation could have materialized if some kind of incentives were given to residents who have initiated the construction of latrines in their own houses and maintain proper sanitation in their areas. Any tangible benefits associated with their efforts in keeping good sanitation will encourage residents who are reluctant to construct their household latrines to do so. The respondents' view is that bye-laws alone cannot solve an issue like open defecation.

Provision of additional public toilets

The construction of public toilets is the least preferred option. Attention is now shifting from the provision of public toilets to household latrines. This may be attributed to the conspicuous nature of public toilets in exposing dirt in towns and cities under situations of poor management. Even, instances, where public toilets are even well managed the unpleasant odour emanating from such toilets, are not controlled. However, household respondents in Gambaga and Nalerigu Townships selected for the study were of a different view, suggesting that since they lack the funds to provide their household latrines, the existing public toilets should be renovated and new ones provided because of the growing rate of their population in both Gambaga and Nalerigu Townships; which put pressure on the limited and existing public toilets.

\subsection{Suggestions of the Ways Forward from Environmental and Sanitation Officers}

The following suggestions were given by sanitation workers in the Gambaga - Nalerigu Municipality as ways the menace of open defecation can be curbed in Gambaga and Nalerigu Townships:

There should be strong law enforcement on open defecation; the Municipal Assembly should gazette its byelaws to enable it punish and correct people who misbehave or go against them.

Chiefs, opinion, and religious leaders should support strongly the fight against open defecation by educating their elders and members on the negative effects of open defecation.

Equally, political leaders in Gambaga and Nalerigu Townships should stop interfering when it comes to the prosecution of victims of open defecation.

Environmental and Sanitation Officers need to be assigned to various areas in the two major towns to ensure frequent monitoring or follow-ups on open defecation and sanitation issues in general.

There is a need for Community-Led Total Sanitation (CLTS) exercise in the communities that focuses on igniting a change in sanitation behaviour rather than constructing toilets. CLTS will concentrate on ending open defecation as a first step and entry point in changing behaviour. It starts by enabling people to do their sanitation profile through appraisal, observation, and analysis of their practices of open defecation and the effects these have.

More and frequent public education on the negative effects of open defecation needs to be effectively carried out by Sanitation workers in Gambaga and Nalerigu Townships to change the attitudes of residents towards open defecation and sanitation as a whole. This education should include encouraging residents to construct their household latrines.

\section{Conclusions}

Based on the findings and discussions made, some conclusions have been made from the study:

The people of Gambaga and Nalerigu Townships 
practice open defecation. A phenomenon the people themselves accepted is not a good practice they should be proud of.

Most of the people of Gambaga and Nalerigu economic status cannot permit them to construct their household latrines; though, they are willing to have their own.

Residents in Gambaga and Nalerigu Townships practice open defecation due to the bad odour emanating from the toilets leaving a bad smell on their entire bodies which makes it difficult to mingle with other individuals once they visit the toilets.

Environmental and Sanitation workers are not seen by the residents performing their mandated functions. They are rather seen effectively demarcating lands into plots for people.

\section{Recommendations}

Having discussed the various issues of the research findings, the following recommendations are put forward:

It is recommended that the Municipal Assembly intensifies their sensitization role of educating the residents on the negative effects of open defecation through radio programmes and seminars.

It is recommended that government, Non-Governmental Organizations, and other philanthropists should come to the aid of residents in the towns by giving them some credit facilities to empower them and to enable them to improve on their economic activities especially agriculture to earn enough income for other developmental projects including the construction of household latrines. This will also assist the few who have their household latrines to get money to dislodge faeces from toilet facilities rather than abandoning them to resort to defecating in the bushes.

It is recommended that the Municipal Assembly should take charge of renovating and seeing to the proper maintenance of the existing public toilet facilities. The budgetary allocation should be made by the Municipal Assembly for this purpose and also if possible and appropriately provide additional public toilets to reduce the pressure on the existing ones; thereby resulting in their deterioration.

It is recommended that the Municipal Assembly as an institution should seriously address the menace of open defecation and encourage more engagement between Environmental and Sanitation Workers and residents in these two towns in terms of environmental and sanitation issues including the elimination of open defecation.

Finally, it is recommended that inadequate financial support from the Municipal Assembly to the Environmental and Sanitation Department to carry out their monitoring and supervision effectively. This will also enable more Environmental and Sanitation workers to be assigned to various areas in towns to ensure proper maintenance of public toilets in Gambaga and Nalerigu Townships and to also check open defecation practices.

\section{Author Contributions}

Ibrahim Abudulai conceptualized the idea, designed the study, analyzed the data, and prepared the manuscript with contributions from the co-authors Tia Abdulai Robert Aziz, Benjamin Ofori, and Godfred Atta Adjei who took part in the fieldwork and the review of the manuscript.

\section{Conflicts of Interest}

The authors declare no conflict of competing interests.

\section{Acknowledgements}

We sincerely thank Dr. Seth Peter Frimpong of the Department of Social Studies Education, University of Education, Winneba for final review of this research.

\section{References}

[1] Republic of Ghana (2010). Environmental Sanitation Policy, Accra: Ministry of Local Government and Rural Development

[2] Sharp, A. M., Register, C. A., \& Grimes P. W. (2002). Economics of social issues (15th ed.). New York: McGraw Hill.

[3] Connor, R. (2015). The United Nations world water development report: water for a sustainable world (Vol. 1). UNESCO Publishing.

[4] Water Aid (2012). Water and Sanitation Sector Overview. Accra: Water and Sanitation Sector Monitoring Platform.

[5] UNICEF/CDD and CSPS (2020). Ghana District League Table II Report. www.unicef.org/ghana/www.cddgh.org.

[6] Annex, B. (2014). Review of literature and anecdotal accounts DRAFT.

[7] UNICEF (2018). Game plan to end open defecation. Programme Division/WASH 3 United Nations Plaza New York, NY 10017 USA.

[8] Ghana Statistical Service (2014). 2010 Population and Housing Census District Analysis Report, East Mamprusi District. Accra: Ghana Statistical Service.

[9] World Bank, World Development Report (2015). Mind, Society, and Behavior, Washington, DC, USA.

[10] Osumanu, I. K., \& Kosoe, E. A. (2018). Where do I answer nature's call? An assessment of accessibility and utilization of toilet facilities in Wa, Ghana. Ghana Journal of Geography, 5 (1), 17-31.

[11] Boschi-Pinto C., Lanata, C. F. \& Black, R. E. (2009). Maternal and Child Health. United States: Springer.

[12] Jones, H., Fisher, J. \& Reed, R. (2012). Water and sanitation for all in low-income countries. Proceedings of the Institution of Civil Engineer-Municipal Engineer, 165: 167-74.

[13] WHO/UNICEF (2013). Progress on Sanitation and Drinking Water. 
[14] Reilly, O. \& Kathleen (2016). "From toilet insecurity to toilet security: creating safe sanitation for women and girls". Wiley Interdisciplinary Reviews: Water. 3 (1): 19-24. Doi: 10.1002/wat2.112.

[15] Ghana Statistical Service (2013). 2010 Population and Housing Census: Summary Report of Results. Accra: Ghana Statistical service.

[16] Pruss-Ustun, A., Bos, R., Gore, F. \& Bartram, J. (2008). Safer water, better health: costs, benefits, and sustainability of interventions to protect and promote health: World Health Organization:

http://www.who.int/quantifying_impacts/publications/saferwat er/en/.

[17] WHO \& UNICEF (2017). Progress on drinking water and sanitation, WHO press: https://www.who.int/mediacentre/news/releases/2017/ launchversion-report-jmp-water-sanitation-hygiene.pdf.

[18] Emerson, P. M., Bailey, R. L., Walraven, GEL \& Lindsay, S. W. (2001). Human and other faeces as breeding media of the trachoma vector Musca sorbens. Med Vet Entomol: 2001; 15: 314-20.

[19] Colley, D. G., Bustinduy, A. L., Secor, W. E. \& King, C. H. (2014). Human schistosomiasis. Lancet; 383: 2253-64.
[20] Ziegelbauer, K., Speich, B., Mäusezahl, D. Bos, R. \& Keiser, J (2012). Effect of sanitation on soil-transmitted helminth infection: systematic review and Meta-analysis. PLoS Med. 2012. https://doi.org/10.1371/journal.pmed.1001162.

[21] United Nations (2009). Promotion and protection of all human rights, civil, political, economic, social and cultural rights, including the right to development: Report of the independent expert on the issue of human rights obligations related to access to safe drinking water and sanitation, Catarina de Albuquerque:

http://ap.ohchr.org/documents/alldocs.aspx?doc_id=15861.

[22] Creswell, J. W. (2014). Research Design: Qualitative, Quantitative and Mixed Methods Approaches (4th ed.). Thousand Oakes, CA: Sage.

[23] Feris, L. (2015). The Human Right to Sanitation: A critique on the Absence of Environmental Considerations. Review of European, Comparative \& International Environmental Law, 24 (1), 16-26.

[24] Bartram, J., \& Cairncross, S. (2010). Hygiene, Sanitation, and Water: forgotten foundations of health. PLoS Med, 7 (11), e1000367.

[25] Korem, A. (1985). Bush Fire and Agricultural Development in Ghana. Accra: Ghana Publishing Corporation, 122-158. 